\title{
A German-Christian Network of Letters in Colonial Africa as a Repository for 'Ordinary' Biographies of Women, 1931-1967
}

\author{
Lize Kriel \\ University of Pretoria
}

This study explores the possibilities of extracting biographies of 'ordinary Africans', especially women, from the epistolary networks of a transcontinental Lutheran community of readers. Due to the enthusiastic efforts of a number of German deaconesses, women from British colonial Africa whose narrations might otherwise not have been recorded, participated in conversations with women in Nazi, and thereafter West as well as East Germany. Mission evidence supports the argument that in colonial Africa religion opened up one of the few spaces for African and European women to collaborate in an otherwise segregated society. While the network was initiated in the name of their common faith and sustained with German church funding (and British colonial infrastructure), the content of the letters was far from restricted to religious matters. The article contends that these epistles reflected an awareness amongst rural female African participants of their position in a much larger geopolitical space - and even a world church. Thus the label 'ordinary' refers to the status of the African women writers in their local communities and church congregations rather than their horizons of expectation. Their fragmentary biographies or life-histories, from both colonial Tanganyika and the Transvaal, need to be viewed within the context of their interaction with their German facilitators and the members of the female Christian reading community in Europe - who were the intended audience envisaged by the African women narrators.

The overwhelming majority of non-western participants in the missionary enterprise are nameless: 'native agent,' or 'bible woman,' or 'native teacher' is how they appear in the missionary records, and in the missionary narratives of white, male, clerical heroism. It is almost impossible to restore the full extent of non-western agency in the building of Christian institutions in the British empire, and the British imperial sphere of influence, but any accurate history must repeatedly look for and acknowledge those acts of participation.

Jeffrey $\operatorname{Cox}^{1}$

\section{Introduction}

The textual legacy of European missionary societies is as vast as it is diverse. The Berlin Missionary Society (BMS) is no exception. By the 1930s, alongside the periodicals, tracts and books which kept supporters of the mission 'at home' informed about the situation 'abroad', the textual offering for 'missionised' readers in Africa and in China included translated Bibles, vernacular hymn books, educational material, calendars and newspapers. Besides the published material, missionaries' diaries and reports were submitted periodically (to the mission headquarters in Berlin) and correspondence in the form of letters also circulated between Berlin and the 'overseas' mission stations. Selections from this (initially hand-written and later typed) reportage found their way into the published periodicals that were aimed at

\footnotetext{
${ }^{1}$ J. Cox, The British Missionary Enterprise since 1700 (London, Routledge, 2008), p. 16.
} 
German readers, also in translation if the writers were indigenous Christians. ${ }^{2}$ But sharing news via letters, in their unpublished form, amongst readers in the 'mission field' as well as in Europe, was also a vibrant part of Christian practice, especially amongst women. As the examination of a network of readers in East Africa, South Africa and Berlin in this study will illustrate, such letters are not only a reservoir of information about daily life on mission stations, but also about the ways in which these lives were 'staged' for far-away audiences, and vice versa. ${ }^{3}$

For the continual flow of the transcontinental correspondence between the supporters of mission in Europe and the 'missionised' in Africa, the local interaction between missionaries and their congregations was crucial. Periodical literature produced in Africa was sometimes employed to facilitate this. In 1955 the missionary wife Thea Johannsmeier published a short article entitled Modiro Basading ('Women's Work') in one such publication: Tsupa-Mabaka a Kereke, the annual calendar for the Northern Sotho-speaking Lutheran congregations in what was then the Transvaal Province of South Africa. Her intention was to introduce these church communities to a practice which was then still fairly new in South Africa, although it had been common in the Berlin Mission in East Africa from the 1930s:

In certain congregations we have seen a sister who is a pastor or a woman evangelist. In the past we didn't have such in most congregations of our Lutheran churches, and we don't know them yet. But nowadays they are sent from overseas by our fathers. Because this is a new thing, I will tell you about the work of women here in South Africa which is a teaching task for women, what they should do is to teach. ${ }^{4}$

Thea Johannsmeier then briefly sketched the life story of Sister Anna von Waldow, at the time working in Venda in the northernmost part of the Transvaal (amongst other things, she had started a TsiVenda newspaper for women). A picture of the sister in a white habit, posing in front of the buildings of Beuster Mission Station, is included. On the next page appears a picture of several other German sisters, amongst them Anneliese Dörfer, posing with unnamed African women from Botshabelo, the training centre of the Berlin Missionary Society in the Transvaal. The picture is not directly related to the article within which it has been placed, but in a way it is relevant, because the piece, written by a local pastor, pays homage to the exemplary life of a local Christian woman, Martha Aphane. No photograph of Martha Aphane appears, and yet her explicit naming and her life story, in print, get to frame the

\footnotetext{
${ }^{2}$ H. Lehmann, Zur Zeit und zur Unzeit. Geschichte der Berliner Mission 1918-1972 III (Berlin, Berliner Missionswerk, 1989), p. 909, provides a list of the most prominent periodicals in Germany. Besides the ones published by the Berlin Missionary Society specifically - Berliner Missionsberichte (1833-1940), Der Ruf(1953-1975) - there were also several which promoted missionary work in general, amongst others: Evangelische Missionszeitschrift (1940-1973), Mission und Unterricht (19131940), Mission und Pfarrampt (1908-1941), Der Missionsfreund (1846-1939) and Die Deutschen Evangelischen Heidenmissionen (est. 1925).

${ }^{3}$ Isabel Hofmeyr has written graphically about the 'Congo mimicry' of the Camden Road Baptists in England. See The Portable Bunyan. A Transnational History of The Pilgrim's Progress (Johannesburg, Wits University Press, 2004), p. 52: 'Letters and articles from missionaries personalized these converts for a home audience.'

${ }^{4}$ T. Johannsmeier, 'Modiro Basading', Tsupa Mabaka a Kereke (1955), pp. 58-60. Thanks to Bethuel Sathekge for the translation from Northern Sotho into English.
} 
picture of the nameless fellow Sotho Lutheran women whose visual images are being featured.

These two juxtaposed contributions to the 1955 calendar, one by a German missionary wife about a deaconess who had come from Germany to work amongst Africans, and one by an African pastor about an African woman working in her local congregation, confirm, as shown of other Christian missionised communities in southern Africa, ${ }^{5}$ that the biographies of European and African sisters can hardly be considered separately. In the textual legacy of the Berlin Missionary Society, German women's lives tend to have been recorded more thoroughly than those of African Christian women (other than those whose life stories had the potential to be cast as ideal-type conversion narratives in publications). Certainly this imbalance in the sources frustrates aspirations towards the composition, 'contrapuntally' (to borrow Said's word), ${ }^{6}$ of biographies recognising the shared life stories of women from both parties, especially if one intends a kind of history empathetic to the daily rhythms which comprised such a substantial proportion of all these women's ordinary lives regardless of how differently the drum beat for German and African women in colonial settings. ${ }^{7}$

It may not all have been intentional, but Thea Johannsmeier's reference to the epistles of Paul and the early Christian deaconess Phoebe aptly captures the role modern-day deaconesses like sisters Anna von Waldow and Anneliese Dörfer played in connecting African and German faith communities:

In the last letter of Paul in Romans we hear him say: I send you Phoebe our sister, who is a sister in Cenchreae congregation. Please welcome her in the name of Christ, as would be appropriate to Christians (Romans 16, 1-2). She, Phoebe, whom Paul called his sister, she has been serving in the Lord's congregation. It is she who sent the letters of the disciples in the city of Rome so that they could be taught from it. With all that: in most Christian congregations they start to have sisters in the field, who help many congregations. We thank our fathers who saw to this from the Berlin Mission, and sent us sisters to come and serve here in our congregation. ${ }^{8}$

The documentary legacy left by mission sisters like Von Waldow and Dörfer, who had been associated with the Berlin Mission from the 1930s in British East Africa and

\footnotetext{
${ }^{5}$ See, for example: D. Gaitskell, 'Female Faith and the Politics of the Personal: Five Mission Encounters in Twentieth-Century South Africa', Feminist Review, 65, (2000), pp. 68-91; D.L. Robert (ed), Gospel Bearers, Gender Barriers. Missionary Women in the Twentieth Century (Maryknoll, Orbis, 2002); R.C. Brouwer, Modern Women, Modernising Men. The Changing Missions of Three Professional Women in Asia and Africa, 1902-69 (Vancouver, UBC Press, 2002).

${ }^{6}$ Edward Said, Culture and Imperialism (London, Vintage, 1993), p. 59.

7 The tried and tested methodology of interviewing the elderly for their reminiscences has been deliberately left out of the equation for the purposes of this paper, because of the separate dynamics of the selective discursive processes noted by S. Field, 'Turning up the Volume: Dialogues about Memory create Oral Histories', South African Historical Journal, 60,2 (2008), p. 180. Ascribing meaning to information obtained through interviews conducted sixty years after the event (and grappling with the role of social memory and historical consciousness in these constructions) on the one hand, differs from the (equally selective and discursive) process of reading the correspondence composed at the time, on the other hand. Merging these two projects will hopefully be attempted in a subsequent stage of this study.

${ }^{8}$ T. Johannsmeier, 'Modiro Basading', Tsupa Mabaka a Kereke (1955), pp. 58-60.
} 
until the 1960s in the Transvaal, was epistolary in form and content. With this article I attempt to imagine the transcontinental community of readers to which the correspondence in these two sisters' files in the archives of the Berlin Missionary Society bears testimony: women who found themselves statutorily immersed in a British world, ${ }^{9}$ but who imagined themselves part of a Lutheran Christian universe. This study argues that epistolary networks are repositories for biographical information which can richly supplement published life histories of the kind the Tsupa Mabaka produced on Von Waldow and Martha Aphane.

As prospective portholes for a view of some ordinary African Christian women's biographies, Anna von Waldow and Anneliese Dörfer's documentary legacies make for productive juxtapositioning. But before looking at the parallel development of their careers, some background about the German Lutheran deaconess movement is necessary. Beginning in Kaiserswerth in 1836, this movement gained new momentum in the last quarter of the nineteenth century as a spiritual response to the social challenges resulting from the economic depression which coincided with the early years of the Second German Empire. It also offered the somewhat contradictory opportunity for unmarried or young widowed women to combine a life of service (under the discipline and protection of a Mother House) with a professional career, either as a teacher, nurse or social worker. Unlike Catholic nuns, Lutheran deaconesses did not take vows, and they could leave the order of their Mother Houses if they decided to abandon a life of celibacy and get married. Most, however, like Von Waldow and Dörfer, dedicated their whole adult life to their work. With increasing opportunities opening up for women after the Second World War to be single, respectable and follow a career, the deaconess movement waned. Over the past few decades, many Mother Houses have been converted into old age homes for the aging sisters as the intake of new deaconesses dwindled from year to year. Deaconesses like Von Waldow and Dörfer who went abroad as missionaries at a young age and returned to the Mother House only on retirement, were the exception. Their work was nevertheless staunchly supported and monitored by the deaconesses who remained based at their Mother Houses and working within Germany. ${ }^{10}$

Both Von Waldow and Dörfer were seconded to the Berlin Missionary Society by their respective Mother Houses (Paul Gerhardt Stift and Salem-Lichtenrade) fairly early on in their careers as deaconesses. They both started their work for the Berlin Mission in East Africa during the years between the two world wars, Sister Anna amongst the Zaramo of Maneromango and Sister Anneliese amongst the Nyakyusa of Itete. Like most German nationals, they were both forced to leave the British territory in 1940: Von Waldow was interned in what was then Southern Rhodesia and Dörfer was deported to Germany, where she worked as a nurse on the Eastern Front. When, after the Second World War, Germans were allowed to resume mission work, they

\footnotetext{
${ }^{9}$ Of course, especially after their withdrawal from the Commonwealth in 1960, South Africa's formal partnership with 'the British world' was compromised, but I would argue that what Cox refers to as 'the British imperial sphere of influence' had relevance to the history of the Transvaal well beyond this date.

${ }^{10}$ L. Stempin, ,Das Diakonissen-Mutterhaus Salem-Lichtenrade', in A. Pfotenhauer \& G. Freytag (eds.), Zeit aus Gottes Hand. 100 Jahre Schwesterschaft des Diakonissen-Mutterhaus SalemLicthenrade (Bad Gandersheim, Diakonissen-Verein Salem-Lichtenrade, 2006), pp. 24-28, Diakonissenmutterhaus, <http://www.paulgerhardtstift.de/Diakonissen.php> , retrieved 7 March 2012. Also various interviews with archivist Anneliese Pfotenhauer at the Deaconesses' Mother House Salem Lichtenrade, Bad Gandersheim, Germany, December 2006.
} 
both came to the Transvaal where, as noted by Thea Johannsmeier in the quotation above, they were perceived by the established Lutheran community as somewhat of a novelty. ${ }^{11}$ Whereas Von Waldow, who was a qualified social worker, had taught as a missionary from early on in her career, Anneliese Dörfer was first and foremost a nurse. She formally turned to teaching and 'women's work' only after her arrival in South Africa, when the authorities declined to acknowledge her nursing qualifications because they had not been obtained within the British Empire. ${ }^{12}$

\section{Berlin Missionary Women's Epistolary Networks in Africa}

Women in Germany were supporting the work of the Berlin Missionary Society from the very beginning. Initially, they formed sewing societies to provide clothing for the missionaries who were sent to China and Africa. By the beginning of the twentieth century there were various women's associations who supported teachers and nurses in the mission field. In 1925 most of these organisations amalgamated into the Berlin Women's Missionary Association (Berliner Frauenmissionsbund). They entered into a formal partnership with the Berlin Missionary Society, taking responsibility for placing female nurses, teachers and evangelists at the disposal of the Society. Epistolary networks between the female workers of the Missionary Society in Africa and the supporters of missionary work in Berlin flourished with the Women's Missionary Association's increasing cooperation with the women's groups of the German churches in the 1920s and 1930s. These women, who were not formally part of the Missionary Society, but eagerly raised funds for them in their congregations, wanted to correspond with the sisters they were supporting in the mission field. The growing collaboration was auspicious, enabling German women's support of missionary work to continue under the wing of the church, within the Protestant Imperial Women's Service (Evangelische Reichsfrauenhilfe), when the National Socialists ordered the dissolution of the Women's Missionary Association in $1936 .{ }^{13}$

Missionary sisters working abroad, like Von Waldow and Dörfer, were expected to report about their work to both their Deaconess Mother Houses and the Berlin Missionary Society (until 1936, specifically the Women's Missionary Association). The Association published many of these letters in their magazine, Aus zwei Welten ('From Two Worlds'), and some of the mother houses also had their own in-house publications (Anneliese Dörfer's Mother House, Salem-Lichtenrade, published the Glaubensgru $\beta$ ('Greeting in the Faith'). A far more extensive bulk of unpublished material was circulated amongst the various Support Groups of each of the individual sisters working for the Berlin Mission. And as the name indicates, these groups

\footnotetext{
${ }^{11}$ See L. Kriel, 'German Deaconesses and the Patriarchy of the Berlin Mission in Apartheid Transvaal', Comparativ. Zeitschrift für Globalgeschichte und vergleichende Gesellschaftsforschung, 5/6, 17 (2007), pp. 55-75. Also see G. Pakendorf, "For there is no Power but of God." The Berlin Mission and the Challenges of Colonial South Africa', Missionalia, 25 (1997), pp. 255-273, for comments on the Berlin missionaries' 'increasing acceptance of and cooperation' with 'the white rulers of the land' and, simultaneously, a growing distance between these missionaries and their black congregations. He ascribes this to the co-existence of missionary and Boer families as a privileged racial minority over several generations. Workers of the Berlin Mission who arrived in South Africa after the Second World War (the deaconesses amongst them) of course did not share this legacy.

${ }^{12}$ Archives of the Berlin Missionary Society (hereafter BMW): Personal files of Anna von Waldow and Anneliese Dörfer; K. Fiedler, Christianity and African Culture. Conservative German Protestant Missionaries in Tanzania, 1900-1940 (Leiden, Brill, 1996), pp. 97-103.

${ }^{13}$ Lehmann, Zur Zeit und zur Unzeit, pp. 649-653 \& 737-8.
} 
assisted the sisters by responding to their requests for (material) support, from teaching material for school children to fabric leftovers for sewing projects. However, as the instructions accompanying one of Von Waldow's first Circulars (Rundbriefe) indicate, supporters were not supposed to make up parcels of books and fabric as a substitute for their regular monetary contributions to the Mission's funds. ${ }^{14}$

The members of the support groups assembled in their congregations in order to pray for 'their sister' and her work. They also assured her of their support by writing to her. It is conceivable that some support groups adopted more than one sister. In their letters, some directed to the Missionary Society and others directly to the sisters, they were barely able to hide their curiosity about life in Africa. They wanted news about the congregation and about the individuals who still needed to be converted. The more they learnt, the more they wished to know. The more responsive a sister was, the more likely it was that her support group would grow and remain active. Anna von Waldow embraced the concept. In the 1930s, her support group consisted of the Young Sisters at Paul Gerhardt-Stift (her Mother House), the Nurses-in-Training at Paul Gerhardt, and a dozen other girls' societies and children's missionary groups associated with various congregations throughout Berlin. Two or three times a year they received a circular from Von Waldow, who also encouraged the members of her congregation and the pupils in her school in Maneromango to write letters for this audience in Germany. She prepared the content of the circulars in Africa (including the translation of KiSwahili letters into German) and posted it to the mission headquarters in Berlin. There, Alice Bühring (one of the foremost spokeswomen for the Women's Missionary Association and also the editor of the women's magazine Aus zwei Welten) distributed it for circulation amongst the various cells of the support group, sometimes with introductory notes and even instructions on how to read the circular together with the current issue of Aus Zwei Welten. Circulars were thus not publications in the strict sense of the word and their content was personalised for each specific support group. It is not clear exactly how many copies Bühring prepared (by 1929 Aus zwei Welten had a print run of 4,400$)^{15}$, but the intention was that members of the support group should read the Circular together at their regular gatherings.

Von Waldow was quick to embrace the art of staging 'letter-writing performances' for collective audiences, particularly of women and girl readers in Germany. In contrast, Anneliese Dörfer, who championed the letter as a medium for private conversation, had to be coaxed into submitting more than her obligatory periodical reports. Indeed, Alice Bühring was forced to scrape together information from other letters sent by Dörfer to the Mission or to her Mother House in order to compile a circular for Dörfer's support group. ${ }^{16}$

After the Second World War, when the Berlin Missionary Society started resuming their work from within the Soviet-backed German Democratic Republic, the circulars, now called Freundesbriefe (letters to friends) were marked as strictly only for circulation amongst supporters of missionary work, and not for general information of the congregation. During the 1950s, and significantly more so after the erection of the

\footnotetext{
${ }^{14}$ BMW 4346: Circulars of Anna von Waldow, 1931-1938, Circular 2, 1931.

${ }^{15}$ Lehmann, Zur Zeit und zur Unzeit, p. 652.

${ }^{16}$ BMW 3029: Alice Bühring to Girls' Group in Storkow, 27 November 1956. The mother houses and the Berlin Missionary Society had agreements that they would exchange all correspondence received from sisters.
} 
Wall in 1961, many of the tasks of the Mission House in East Berlin were taken over by the new Berlin Mission office in the western part of the city, where Alice Bühring edited a new magazine. ${ }^{17}$ Called $\operatorname{Der} R u f$ ('The Call'), this magazine was no longer aimed exclusively at women's work, but served as the replacement for the Berliner Missionsberichte which had been the Society's official mouthpiece throughout the nineteenth century. The circulation of the new magazine in East Germany was prohibited by the East German authorities. Therefore, East German supporters of the mission relied heavily on the discreet distribution of the Freundesbriefe. Private letters posted between East and West Germany assumed a new role in this period in conveying more personal, confidential and potentially politically sensitive information across the divide. For example, Anneliese Dörfer's Mother House relocated to Bad Gandersheim in the western part of Germany after the war. The epistolary exchange between the Mother House, the mission stations in the Transvaal, the Mission House in East Berlin and the new Berlin Mission office in West Berlin continued beyond Dörfer's retirement to Bad Gandersheim to her death in 1986.

African participation in this transcontinental network of exchange was not restricted to letters written on Von Waldow's encouragement or the emulation of the German periodical's style in local missionary publications. This is shown by a significant body of evidence that was preserved in the sisters' files in the BMS archives. It comprises colour drawings by Tanganyikan children dating from the 1930s, alongside typewritten transcriptions and translations of letters from KiSwahili, Northern Sotho and TsiVenda. They had either been forwarded to the Mission House by the sisters or posted to sisters during the periods of their absence from Africa (first from 1940 to the early 1950s as a result of the Second World War and then after their retirement in the 1960s). These letters show that African writers had no problem switching styles from addressing a collective audience to writing a personal letter to an individual missionary. This textual evidence suggests that, much as happened on the German side, news from letters was spread orally amongst African congregations, reaching more than just individual correspondents.

\section{Biography, Epistolarity and Fiction}

The biographical information that can be harvested from an epistolary network dominated by women shows many resemblances to, but is not identical with, the more conventional, and more widespread, missionary-choreographed 'personal accounts of the newly converted in the form of life stories and autobiographies ${ }^{18}$ that were published in missionary periodicals and tracts. Gareth Griffiths' assessment of these mission biographies / life stories / autobiographies offers valuable insights that are also relevant to the somewhat different set of manuscripts and print material examined here.

Griffiths' unit of study is the published life story. In his 'close analysis of recaptive life stories and personal conversion narratives produced from the 1870 s to the 1920 s', ${ }^{19}$ he reveals the relationship of control established by the missionary interviewer / amanuensis over the converted interviewee, and the further manipulation of that text to conform to narrative conventions subscribed to in

\footnotetext{
${ }^{17}$ Lehmann, Zur Zeit und zur Unzeit, pp. 801-812.

${ }^{18}$ G. Griffiths, ' "Trained to Tell the Truth': Missionaries, Converts and Narration', in N. Etherington (ed.), Missions and Empire (Oxford and New York, Oxford University Press, 2005), p. 152.

${ }^{19}$ Ibid., 155.
} 
missionary publications. He illustrates how these narratives were shaped to obtain a 'generic quality', of which the 'stereotypical nature is part of the design and the foundation of the claim it makes on its intended audience of mission supporters at home'. ${ }^{20} \mathrm{He}$ reads the life stories against the grain to conclude that in the published texts, "speaker and spoken stand ... as intimate enemies, bound together linked in an unequal process of self-definition'. ${ }^{21}$ The narratives should however not only be seen as instruments of oppression, but also as a possible means of resistance. Griffiths demonstrates that, "even in the most unfavourable circumstances, the voices of the colonised subjects cannot be completely suppressed'. ${ }^{22}$

Turning to the unpublished correspondence archived in the personal files of deaconesses like Dörfer and Von Waldow, unequal relationships of the kind Griffiths describes are bound to be replicated, considering how familiar the letter writers were with missionary publishing conventions. But they also represent a discursive space of a different kind, where the intimacy of letter-writing and the socialising potential of communal letter-reading resulted in the production of biographical information which need not necessarily be interpreted in the context of narratives of either oppression or resistance.

Certainly it is no new thing for historians to study letters. A little more than a decade ago, William Merrill Decker remarked:

As archival documents, letters have never suffered neglect: they have long been read as primary sources of biography and history, as texts brimming with informational content. Yet the performative, fictive, and textual dimensions of letter writing, and the artifacticity of the personally inscribed holograph, have only recently attracted serious notice. ${ }^{23}$

In 1982 Janet Gurkin Altman laid a foundation for an analytical approach to letterwriting as a form. She described epistolarity as 'the use of the letter's formal properties to create meaning' and 'the phenomenon of storytelling through letters'. ${ }^{24}$ Applied to the archival material at hand, this immediately brings one back to the ethnographer's tried and trusted dictum that accountable evidence can seldom be acquired in a single interview, but that multiple encounters with a witness over an extended period of time offer a far richer yield. The biographical material about the women who lived amongst the missionaries in East and in South Africa and who intrigued and inspired the women readers in Berlin, ${ }^{25}$ is not gleaned from the exchange of letters in a single composition resembling the stereotypical account of a

\footnotetext{
${ }^{20}$ Ibid., 160.

${ }^{21}$ Ibid., 171.

${ }^{22}$ Ibid., 155.

${ }^{23}$ W.M. Decker, Epistolary Practices. Letter Writing in America before Telecommunications (Chapel Hill, University of North Carolina Press, 1998). Examples of this type or approach which stand out, are N. Z. Davis, Fiction in the Archives: Pardon Tales and their Tellers in Sixteenth-Century France (Stanford, Stanford University Press, 1990) and R. Chartier and C. Dauphine, Correspondence: Models of Letter-writing from the Middle Ages to the Nineteenth Century (Princeton University Press, 1997). Karin Barber's edited volume, Africa's Hidden Histories: Everyday Literacy and Making the Self (Bloomington, Indiana University Press, 2006) contains various contributions focusing on letterwriting.

${ }^{24}$ J.G. Altman, Epistolarity. Approaches to a Form (Columbus, Ohio State University, 1982), pp. 3-10.

${ }^{25}$ And certainly we must not rule out that the African women may have been equally intrigued by their Christian sisters in Europe.
} 
desolation-to-salvation trajectory. Rather, the biographer can 'harvest' information from conversations within a transcontinental community of Christian readers that continued in the course of many letters over an extended period of time.

Altman argues that we should not lose sight of the transcendental capacity of the epistolary form by staring ourselves blind over the technicalities of postage, delays in delivery, precise translation or even loss of letters. Significant as these issues are, they should not distract our attention from the imaginary network that is invented by the participant in an epistolary community. ${ }^{26}$ As Isabel Hofmeyr points out, sensitive as we ought to be about interpretation by amanuenses and censorship through translation and publication, we should also broaden our conceptions of reading: 'African readers utilize the idea of circulation to project themselves into a transnational arena above or beyond the colonial state'. ${ }^{27}$ In both Germany and in Africa the letters received were read out aloud on occasion; the ability to participate in the exchange did not presuppose, and the actual exchange of information did not necessitate, the individual act of putting pen to paper or hand on typewriter for every single member of the community of readers. The mere understanding that letters can convey personal messages, thoughts, laments, desires and curiosity over distances much further than the body can travel, broadened the horizons of German and African women alike. Furthermore (as will be illustrated in the examples below), on the ground in Africa the close collaboration of German and African women in epistolary consumption and production generated tensions and opened opportunities for presumed hierarchies of oppression and subjugation to be questioned.

For Altman, epistolarity offers the possibility for the invention of a new history. Just as Gaitskell argues for Christian women's 'politics of the personal ${ }^{28}$ while Hall searches for actual patterns of consumption beyond or beside revelations of 'domination, subversion and resistance', ${ }^{29}$ so Altman finds a new direction in women's challenging of the traditional Western epistolary myth. Not surprisingly, this tradition (going back to classical antiquity), in which man explored and conquered, and woman waited and responded, was also precisely what the female Christians driving the network of readers were hoping to change about the European missionary endeavour in colonial Africa.

\section{Biographical Glimpses of African Women from Anna von Waldow's Circular Letters}

Von Waldow's networking capabilities can be more fully appreciated when read against the background of Dörfer's rather clumsy early attempts at reporting back to Germany. Dörfer's first letters 'home', after her arrival in East Africa in 1936, depict African women as being in desperate need of rescue from 'tribal' and Islamic subjection: 'Indeed I feel the necessity to comprehend the plight of the women by conducting one-on-one interviews. She is so despised and is certainly not valued as a

\footnotetext{
${ }^{26}$ J.G. Altman, 'Graffigny’s Epistemology and the Emergence of Third-World Ideology', in E.C. Goldsmith (ed), Writing the Female Voice. Essays on Epistolary Literature (Boston, Northeastern University Press, 1989), pp. 172-203.

${ }^{27}$ I. Hofmeyr, 'The Globe in the Text: Towards a Transnational History of the Book', African Studies, 46,1 (2005), p. 9.

${ }^{28}$ Gaitskell, 'Female Faith', pp. 68-70, in response to Meera Kosambi and Jane Haggis.

${ }^{29}$ Hall is quoted by S. Robbins, 'Women's Work for Women: Gendered Print Culture in American Mission Movement Narratives', in J. Dankey and W. Wiegand (eds), Women in Print (Madison, University of Wisconsin Press, 2003), p. 259.
} 
human. I think it is most beautiful to bring them to the Gospel. ${ }^{30}$ Nevertheless, the extracts from her letters that were selected for publication in the periodical Der Missionsfreund ('Friend of the Mission') of 1939, feature Anneliese Dörfer's own story and not the stories of African women. A paragraph which was not included for publication gives an impression of how Dörfer's early intentions must have been checked by the local limitations to her agency. In April 1937, only some months after her arrival in East Africa, she was left 'alone' on the Itete Mission Station by the other German members of the Society, and she reported that she spent a number of days in quite a state of fear, until Seleka, a local woman and elder in the congregation, entered her house, stating: 'I want to stay with you and I want to help you, also with learning the [our] language; we shall be steadfast as a mountain.' ${ }^{31}$ Dörfer's letters do not offer enough information for a full-length biography of Seleka, but this unpublished sentence says much about the refusal by an African woman of language that, in Altman's terms, hierarchises relationships. ${ }^{32}$ Here Dörfer, supposedly the missionary/coloniser-teacher, is being taught - and strengthened - by one of those who were supposed to be the recipients of her 'wisdom'.

Anna von Waldow was indebted to Africans for a similar learning experience. The Berlin missionaries' correspondence cast her as coming to Africa to assist the local elder, Ruth bindi Ulembo. Ruth herself, however, regularly takes the stage in Von Waldow's correspondence as a woman who ascribes assistance directly to God and the prayers of fellow Christians worldwide, but not to missionary interventions. One can trace a number of moments in Ruth and Von Waldow's conversations, with one another and with women in Germany, which help illustrate the making of 'counterpunctual' biographical vignettes through the practice of epistolarity. The following is an extract from Anna von Waldow's eighth circular, posted on 8 June 1933 for collective consumption by the large group of supporters of her work in Berlin:

This letter serves to thank you all from the heart for your kind greetings and to answer your questions. My daughters wish in particular to thank the Waana Wali $^{33}$ of the Housekeeping School of the Paul Gerhardt-Stift, of Philipp Apostel and of Kapernaum. Your pictures gave them a lot of joy. Everyone immediately picked themselves a friend. Every evening, before the collective prayer, one of the girls takes a turn to speak a thought of her own. On this evening Lili said: 'Also take care of the German Wali; and we thank you Lord for the great joy, that we have received a letter.'

\footnotetext{
${ }^{30}$ BMW 3029: 1934-1953. Half Year Report, Itete, 1 July - 31 December 1938, January 1939. (All translations from Dörfer and Von Waldow's letters by the author, with corrective assistance from Nora Thoma and Klaudia Ringelmann.)

${ }^{31}$ BMW 3028, 1936-1981: From the Experiences and the Work of Deaconess Anneliese Dörfer, Missionary Sister in Itete/East Africa (Extracts from Letters), Compiled end of 1938.

${ }^{32}$ Altman, 'Graffigny's Epistemology ', pp. 182-183, discussing the eighteenth-century novel, Letters of a Peruvian Woman, writes of the heroine, Zilla: 'She refuses the language of conquest, possession, and triumph that hierarchizes relationships in a self-perpetuating master-slave dichotomy.'

${ }^{33}$ Waana wali can be roughly translated as teenage girls. In Maneromango, Anna von Waldow converted the practice of secluding girls who had reached puberty (Waana Wali) into a Christian schooling system for girls in this stage of life. See Fiedler, Christianity and African Culture, pp. 97103.
} 
And now, to answer your questions. A lot of people have been asking me about Ruth, her husband, parents, brothers \& sisters, children. I asked her to answer the questions herself and she has written the following letter:

'To the mothers. Plenty of greetings and once more plenty of greetings, and I wish that you are in good health. And if you were wondering about the state I am in, I am in good health and all my children are in good health through the power of God and the love of Jesus Christ and the mercy of the Holy Ghost. We thank God for all these things. And more news is the following: I would like to tell you a little about how I have entered our holy religion. I was guided by my mother and my father, but I was baptised before my father, and that was when I was still a child. And my father was also baptised, but my mother was not baptised, so she remained a heathen, also when she died. And another word of affliction is the following: my father abandoned our religion and also two of my brothers, and those are my elder brothers, they were thrown away with my father.

There are three of us, who were born of one mother, who are Christian, and our partners were also called by God, and we are two left: I, Ruth, and my younger sister, Luise, and the one who has died, he was my brother, and the three of us are Christian.

And this one, my elder brother Elia, left six children behind and my sister Luise has six children and my own six children were also called by God. And further, my children have also started to have children. My eldest child has three children (she has married Joseph, the successful trader in town). And my second child has two children (that is Marta, who has married Nahori, the boy of Sister Elfriede and Sister Gertrud). And Maria has just become a Mwali [teenage girl]. And my son Samuel is in Marangu in the Seminary, and Ajuaje is in the second year of school and Sala is still small. And I have taken up the position of Elder twelve years ago. And my husband was a teacher and now he is an elder and that has been for the past three years and his name is Jesaya. And all of this is through the mercy of God the father and his son Jesus Christ. And in all of this you must not neglect praying for us, that we shall experience that our congregation in Maneromango will grow.

Plenty of greetings from Mama Ruth, daughter of Ulembo. ${ }^{34}$

As a conversion narrative, Ruth's letter must have disappointed the conventional missionary expectation that the necessity of their presence in Africa had to be confirmed. Rather, Ruth's account, with its stress on female fecundity and Christian family formation, affirms the growth of the African church of its own accord. Her own spiritual stature emerges in the Pauline language used as she deliberately builds up lists of which family members have been 'called by God' while regretting those 'heathens' or backsliders 'thrown away' (including her own parents).

${ }^{34}$ BMW 4346: Circulars of Anna von Waldow 1931-8. Circular 8, June 1933. 
That Ruth was a woman with a mind of her own also became apparent when she asserted her own will as to whether to write or not to write. In 1936 Anna von Waldow concluded a circular intended for German female readers as follows:

I would like to add one more request. When I asked Ruth to write down her experiences, she asked: 'Why should I? I have still not received an answer.' She was nevertheless immediately willing to write when I told her that 'they were thinking of you in their prayers.' But she should definitely be very happy if she were to receive a small greeting card.

With hearty thanks and faithful thoughts

Yours

$\mathrm{AvW}^{35}$

Von Waldow had ample opportunity for imposing her own strategies on to her network of letters. She decided what news from Germany should be disseminated and which responses were translated and sent to the readers in Berlin. Her attempt to showcase and promote, rather than downplay, Ruth bindi Ulembo's agency must thus have been deliberate and intended. It may be that by sharing with the readers in Berlin Ruth's defiant response upon her request for another letter, von Waldow was trying to teach the German women that if they wanted news from Africa, they should make an effort themselves and write a letter. But it may also be that von Waldow was trying to tone down Ruth's indignation at being expected to write twice in a row with no response in between. After all, Ruth's immediate change of attitude on learning that the German women were praying for her seems rather naive. It appears more likely that von Waldow had to make a greater effort to encourage her to write. However, it is also conceivable that the awareness of being part of this extensive network, together with the prospect of a greeting card just for herself, proved enticing enough to bring her back.

Von Waldow wanted her transcontinental network of letters to be accessible, interactive and discursive. This was a model which gave the network its allure and (not unlike the internet-based social media of our own time) unsettled, rather than secured, her own position of control. She chose this means of knowledge exchange because it enabled her to act out the role of facilitator rather than disseminating centre. Moreover, it prompted women and children to ask questions and write about the politics of the colonial everyday. Even if one wishes to argue that the open and participatory appearance of the network was merely a part of von Waldow's 'show' and that she actually had significant power to prescribe and select what should be included in her circulars, the point remains that the epistolary form could not be moulded entirely to the liking of the designer to the same degree as a singular life history crafted for publication.

Reminded of the prayers of her sisters in Germany, or anticipating a greeting card from them, or out of loyalty to Von Waldow, or simply succumbing to what Ponsonby referred to as the letter writer's 'itch' not only to record but also to relate, ${ }^{36}$ Ruth sat down to report her recent personal experiences. Von Waldow translated her epistle from KiSwahili into German, which reads as follows in English:

\footnotetext{
${ }^{35}$ BMW 4346: Circulars of Anna von Waldow 1931-8. Circular 15, November 1936.

${ }^{36}$ A. Ponsonby, English Diaries. A Review of English Diaries from the Sixteenth to the Twentieth Century with an Introduction on Diary Writing (London, Methuen, 1923), p. 30.
} 
Easter I went to Maneromango to participate in the Holy Communion and to meet again with my relatives. It has in the mean time rained a lot, but I wanted to get back, because my husband Jesaya was alone, and then our millet also had to be harvested. Thus we embarked. What a sight after the first day's travelling! The dry land has been transformed into a lake. We had to cross five very broad streams, often we were up to our necks in the water and often we had to get out again and look for another place to cross. The food we had taken with us for the trip ['safari'] was spoilt. I had no more strength to carry my six-year-old daughter Salazu and gave her to a carrier. When he was in the middle of the water, he sank, and we thought they had both been lost, but God helped us a lot, he came up again and held Sala up with both hands. We thanked God, and we ask you to thank him with us ... ${ }^{37}$

Having read the letter this far, Ruth indeed seems to have broken away from the formulaic (and there is no evidence of Von Waldow protesting). Ruth tells a sympathetic audience of fellow mothers in another Christian community, about the responsibilities of daily life (household and harvest) and her enormous relief when her child survives danger brought about by flooding - which is not interpreted here as a message from God or the devil or the ancestors, or blamed on bad environmental planning by the coloniser-government. But the subsequent section again strongly confirms the possibility of speaking in various voices within a single personal account. ${ }^{38}$ And it offers another morsel of biographical knowledge about Ruth. Having now set the scene with her personal experience of the floods, she continues to relate stories which she had heard from others. She casts them in a mould that confirms the importance of the mission, and the wisdom of the newly converted as opposed to the foolishness of those still holding on to their old ways, as well as the corruption of those who seek to advance in worldly things. A chief's incompetence can comfortably be criticised in front of the audience of German women, as they are unlikely to castigate Ruth for being sceptical about the British system:

And at last we arrived in Kidunda. Oh what a sight! The millet field which I intended to harvest, was a lake. The water had washed away all the harvests, only against the mountain something could be harvested. Great hunger has entered the land. And plenty of houses were swept away by the water. Had we not had our mission's canoe, plenty of people would have died. The crocodiles and the hippos came up to the houses. A crocodile swallowed a fairly big girl. When the askari pori (indigenous elephant hunters, paid by the government) tried to shoot the animal, he suddenly noticed in the tree above him a gigantic snake with its mouth wide open, ready to swallow him, so he shuddered and ran away and in the mean time the crocodile had swallowed the girl.

But we still had much to be grateful for, because the houses at our mission's place and the school were still standing. The water had just come up to the houses. We have seen a lot of hardship, but do the people hear God's word? No, they love their possessions more than the true God. In a neighbouring town they collected money to look for a new god, that is, they were looking for another witch-doctor, who could rescue them from their water troubles. The chief after

\footnotetext{
${ }^{37}$ BMW 4346: Circulars of Anna von Waldow 1931-8. Circular 15, November 1936.

${ }^{38}$ For polyphony and heteroglossia in personal documents, see M. Holquist, Dialogism: Bakhtin and his World (London, Routledge, 1990), pp. 69-70.
} 
a while prohibited the collection, but only because he himself wanted the money as kodi (government taxes). God calls through his punishments, but they will not hear the Word of Jesus. True: a number did hear and started to attend the lessons. There is a Kigoli, an older girl, who is giving me much joy. She is now in the baptismal class and while I have been away, she has cooked well for my husband.

You, our brothers and sisters, do not forget to pray for us. We do have hardships, but in particular pray that the people will hear the Word of Life. We have trouble here in our faraway land, to live separated from our relatives, but we think about the Word of God: 'Where two or three are together, there I am with them'. And to another, he has said: 'Go and teach all the nations, that they become my disciples and baptise them in the Name of the Father and the Son and the Holy Spirit and I am with you all the days.' We have not forgotten that, not a bit. And HE had not forgotten us in all the troubles we have experienced. And we thank God for all his goodness and sing with our father Luther: 'A Safe Stronghold Our God Is Still'. Mzidi Kutuombea. You may carry on to pray for us. Live well.

Ruth bindi Ulembo ${ }^{39}$

Indeed, in isolation from their context the last two paragraphs might have appeared like a formulaic account that offers European readers just the right 'combination of the shocking and the moral ${ }^{40}$ to justify their involvement in Africa. But Ruth cannot be taken to task for their illusions. Through her participation in the network, we get to know Ruth the housekeeper, farmer, writer and reader, but first and foremost the elder. She herself illustrates how she performed all these roles as a woman with a wider view of the world, one who considered herself a member of an international Christian community. She had brothers and sisters in Germany, whom she could remind of their responsibilities and whom she could thus summon to pray for her and her congregation.

Ruth bindi Ulembo is mentioned again in passing, as the wife of the teacher at Kidunda, in a letter written by her fellow elder Salome (whose family name is not provided). This letter was written on Von Waldow's request in order to greet and thank the 'dear sisters, women and mothers' in Berlin. There are two more letters of 'thanks and greetings' which give glimpses of personal lives, this time, of two teenage girls in the baptism class ('Waana Wali'). They appear in Von Waldow's seventeenth circular, which was distributed to various girls' and women's groups in and around Berlin in December 1937. In a previous circular, Von Waldow had promised that the girls in her school would write letters about their experiences. ${ }^{41}$ The two letters by the two girls reveal interesting details about the way in which they imagined their connection to the world abroad. What makes these accounts particularly interesting is that the teenage girl Tuingie Elia and the adult woman Salome reported on the same trip, enabling the readers to compare two different experiences of the same event.

\footnotetext{
${ }^{39}$ BMW 4346: Circulars of Anna von Waldow 1931-8. Circular 15, November 1936.

${ }^{40}$ Griffiths, 'Missionaries, Converts and Narration', p. 158.

${ }^{41}$ BMW 1 4346, Circulars of Anna von Waldow, 1931-8. Anna von Waldow, Maneromango, 7 October 1937.
} 
Salome's letter is introduced by a heading (possibly inserted by Von Waldow): 'As thanks and greeting to our dear sisters, women and mothers'. And then she writes:

To the great mothers

Greetings to our dear brothers and sisters in the name of our Lord Jesus Christ. We would like to know how things are with you. Yes, are you free of any troubles? And if we know how things are with you, we do not have any troubles through the grace of God and his Son Jesus Christ; the cause of our troubles was the sake of the Name of the Lord. ${ }^{42}$

She proceeds to recount their trip. They travelled by car which at some stage got stuck in the sand, forcing them to walk a long distance. They enjoyed much hospitality in the places which they visited. Sisters Anna, Ruth and herself took turns to preach during their visit to Kidunda. On their way back home, they had to sleep in the bush ('lions, elephants and leopards were all around'). Almost as an afterthought, she mentions that they saw a woman possessed by the devil in Kidunda. This is then used as an entry point to summon the 'great mothers' in Germany to pray for them that they might be successful in preaching the Word of God, which she feels she is unable to without Mama Anna (von Waldow). While in this last paragraph she conforms to what Griffiths calls the "determining myth of unchanged and unchangeable heathenism to which only conversion can bring an end', ${ }^{43}$ the animated account in the preceding paragraphs of the letter indeed offered her readers in Berlin a glimpse of the adventures in her own 'post-conversion present', which published autobiographies were unlikely to have offered at the time.

Indeed, Salome's reference to the devil-possessed woman in the tail-end of her narration confirms the extent to which she distances herself from the conventional published autobiographical role of the recently-redeemed heathen. She rather casts herself in the role of travelling preacher, fully appropriating the missionary gaze for herself. Salome does not see herself as like that woman possessed by the Devil. She is not the one in need of conversion; she counts herself amongst those capable of encouraging it amongst others. She concludes the letter with the statement, 'I am Salome, the Elder and your child, because out here I cannot function well without Mama. Many greetings! I am the helper of Mama herdswoman Anna. ${ }^{44}$ I would argue that this does not mean that Salome subjects herself to Von Waldow's authority, or a Europe-Africa hierarchy in the faith, but is, rather, an expression of personal loyalty to Von Waldow, and a voluntary commitment to Von Waldow's leadership. What may have been interpreted as capitulation in a collaboration / resistance paradigm, can also be read as Salome's attempt to construct a sense of belonging, and in a Christian paradigm, an exemplary emulation of the meekness of Christ, and thus a victory,

While Salome was putting her serious dedication as an Elder on display in her letter, Tuingie Elia is keen to share with the German readers how much fun the girls had on the trip. They sang, they played, they were tired and thirsty at times, but they also enjoyed swimming. In sum, it was a great adventure. There are a myriad ways to read this letter. A young woman is trying to compress all the excitement and novelty of a

\footnotetext{
${ }^{42}$ BMW 4346: Circulars of Anna von Waldow 1931-8. Circular 17, December 1937.

${ }^{43}$ Griffiths, 'Missionaries, Converts and Narration', p. 167.

${ }^{44}$ BMW 4346: Circulars of Anna von Waldow 1931-8. Circular 17, December 1937.
} 
trip by motor car into sentences and paragraphs. Apart from the opening and closing paragraphs, she evidently knows no formula to fall back on. Surely many a German girl reading about this adventure would also have wanted to live in 'Africa'. It was a useful letter for von Waldow and Bühring to stimulate further interest in and enthusiasm for their missionary work amongst girl readers.

As regards the form of the letters, a comparison of these two epistles shows that the writers were indeed emulating a type of greeting in which enquiry about the addressees' wellbeing has become formalised (as would have been typical in KiSwahili), while retaining biblical overtones. Salome begins her letter as follows:

Greetings to our beloved brothers and sisters in the name of our Jesus Christ. We wish to know the state you are in. Are you all free of any troubles? And if you would like to know the state we are in, we are free of any troubles through the grace of God and his son Jesus Christ.

And this is how Tuingie Elia greets her readers:

We give you greetings, we, the Waana Wali of Maneromango. Are you free of any troubles? We are yearning for news from you, in order to know if you are all well.

The young women then proceed to elaborate extensively on the basic form in their preambles, each in her idiosyncratic way, indicating the ease with which they had appropriated letter-writing as a medium to make transcontinental links. While Tuingie Elia addressed her letter 'to my beloved teenage girls from Europe', her peer, Mwajabu Jonatani, wrote specifically 'to the German children'. The interchangeable identity of Germany and Europe is noticeable! Mwajabu Jonatani assures the German children that, when the children of Maneromango pray on Sundays, they also pray for 'you over there. May God grant you his blessing and the Holy Spirit.' She concludes: 'And we would like to continue praying and you must continue praying for us a lot.' Tuingie Elia is as convinced as Mwajabu Jonatani that the Christian girls in Europe are being strengthened in their faith through the prayers of the African Christians. She writes:

Further, we are yearning for news about your work and your diligence. Our caretaker, Mama Anna, told us about your work and your diligence, and we have heard this news, and we were happy about it. And Mama, our caretaker, has shown us pictures of you and our country over there, and we were happy about the pictures. And now I think, you, my dear friends, would be happy to hear our news. My dear Waana Wali, I would like to tell you the news about our safari. ${ }^{45}$

Tuingie Elia concludes:

Now my dear Waana Wali over there in Germany, this is the state of our safari to Kifulu and Kidunda. May God help you further. Many greetings to all

\footnotetext{
${ }^{45}$ BMW 4346: Circulars of Anna von Waldow 1931-8. Circular 17, December 1937.
} 
Christians over there, God be with you every day, until we see each other again. $^{46}$

The final words in this paragraph are revealing. They should not be taken as the anticipation of a physical meeting. Rather, they conform to the formula which the German missionaries used to conclude their letters to one another (a type of letter which Von Waldow shared with her pupils); they also echo the greetings of the ancient Christians in the Epistles of the New Testament, including the prospect that all Christians will be united at the second coming of Christ. Therefore, this greeting shows the extent to which Tuingie Elia views the world as comprising Lutherans 'here' and Lutherans 'over there', all belonging to one and the same faith community. ${ }^{47}$

The Second World War terminated the Berlin Missionary Society's work in Maneromango, and with Von Waldow's internment in Southern Rhodesia, the communication between the girls and the women of East Africa and Berlin was also disrupted. But in a letter from 1953 to Professor D. Knak, the superintendent of the Society in Berlin, Von Waldow reported that she had been corresponding with a Finnish woman missionary who had arrived in Maneromango in October 1952, Sister Annikki Holma. From her, Von Waldow had learnt that Ruth bindi Ulembo had died in 1951. In Von Waldow's absence, Ruth had taken over 'Mama Anna's' role. ${ }^{48}$ When Holma arrived, the congregation showed the new 'Mama Anna' a picture of Anna von Waldow. A church member had signed one of the letters sent to Von Waldow in the Transvaal, sending greetings and adding that they still often thought of her.

In the last years of her career, in the Transvaal in the 1950s, Von Waldow again started writing to a collective of German supporters. The circulars, now called 'Freundesbriefe', were again distributed by Alice Bühring but were now all marked 'only for use within the Church' by people trusted to be supportive of missionary work. A request by Bühring ('you can hardly imagine how hungry our most faithful co-workers here are for unvarnished portrayals of reality') ${ }^{49}$ prompted another stream of biographical information about African women. However, the conditions under which Von Waldow worked in South African were very different from her preSecond World War experiences in East Africa. Little experienced in collaborating with woman missionaries, the Transvaal-based leaders of the Berlin Mission were unsure how to employ her. She was often transferred between mission stations and consequently she never properly learnt either TsiVenda or Northern Sotho. Moreover, she was also obliged to get along with the local Afrikaner population and, as a teacher, she became responsible to the apartheid state as Bantu Education was introduced. All these factors made it complicated to build up trusting relationships with Africans, Therefore, there was no chance for her to repeat her East African project to mobilise Africans to convey their own news to readers in Germany.

\footnotetext{
${ }^{46}$ BMW 4346: Circulars of Anna von Waldow 1931-8. Circular 17, December 1937.

${ }^{47}$ In her private letters to Berlin, Anneliese Dörfer spent much energy on reporting the betrayal of this worldview by the missionaries of the BMS.

${ }^{48}$ BMS 4342, Schwester Anna von Waldow 1937-1959, 8 May 1953.

${ }^{49}$ BMW 4342, Schwester Anna von Waldow 1937-1959, A, Bühring to A. Von Waldow, 2 April 1953, Berlin.
} 
In her fourth Letter to Friends, compiled on 7 January 1949, Von Waldow inserts the life story of Hilda Popi, 'the first black nurse in Vendaland', which had been compiled by Thea Johannsmeier. Unlike the biographical narratives that resulted from Von Waldow's earlier attempts to encourage women like Ruth and Salome to relate their stories with an awareness of their discursive relation with an audience in Germany, Hilda Popi's story unfolds together, indeed entwined, with that of her husband, James Madie, Popi's having been told personally to Johannsmeier while Madie gave his as a testimony to the local Venda congregation. What is most striking in their stories is how, despite the influence of the mission society that had invested heavily in the conversion of communities in their mother tongues, Hilda Popi and James Madie became exemplary transcenders of cultural and linguistic boundaries. Madie had studied with the International Holiness Mission ${ }^{50}$ in England. Although both Popi and Madie came from Venda, they had met in Durban, worked in Swaziland and then, at the time of the recording of their life stories, were stationed in Pondoland. However, for the Christmas holiday they returned to Venda, underlining the trans-regional as well as transnational nature of some post-war black South African Christianity.

\section{Dörfer's Letters as Portraits of Female Christianity}

When comparing Von Waldow's style as facilitator with that of Dörfer, it seems as if Von Waldow wanted her epistolary network to emulate paradisiacal relations between Christians. Her focus was on the harmonious and the propensity of letters between Christians to transcend all earthly strife. Her network constituted an imaginary communal space in which everyone put her best foot forward. Not so with Dörfer, who preferred to write privately to particular individuals, such as her superior at the Mother House, the women in charge of women's work at the Berlin Mission Society, or friends at the Society's headquarters. It is not surprising that she sometimes received letters with 'peppered cream' as she herself referred to castigations sent from Berlin. ${ }^{51}$ She regarded it as her duty to expose to Berlin what was hidden by the distance between the 'mission house' and 'mission field'. A recurrent frustration to her was that the management of the Society in Berlin did not always hear (or care for) what the sisters or the local Christians had to say. An example is a letter of complaint which she and some other sisters sent directly to the mission headquarters shortly after her arrival in the Transvaal. In a subsequent letter to her direct supervisor, the mission inspector Alfred Oelke, she apologised that she had bypassed him, explaining, 'to us it seemed as if the whole Berlin Mission was deaf'. ${ }^{52}$ This echoed an earlier letter from her time in East Africa, reporting the agitation of the local congregation about what they perceived as BMS reluctance to act against an adulterous German missionary, finishing with the question, 'Was it possible that the voices of the congregation were really not heard in Berlin?, 53

\footnotetext{
${ }^{50}$ The Holiness Mission, steeped in a Methodist tradition, was founded in London in 1907 and renamed the International Holiness Mission in 1917. They worked extensively in southern Africa. In 1952 they amalgamated with the Church of the Nazarene. See

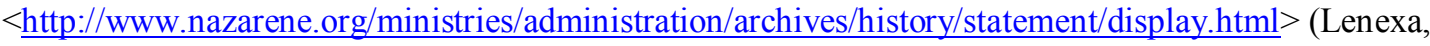
KS, Church of the Nazarene, 2011), retrieved 7 March 2012.

${ }^{51}$ BMW 3028, 1936-1981: A. Dörfer, Botshabelo, to Missionary Inspector A. Oelke, 5 November 1953.

52 Ibid.

${ }^{53}$ BMW 3028, 1936-1981: A. Dörfer, Itete, to Missionary Inspector W. Braun, Berlin, 9 June 1939

(Private Correspondence).
} 
Even though always ready to write (and later type) complaints when she saw injustice in the mission's operation, Dörfer's correspondence style did not create a similar space for local Christians to converse directly with German Christians as had that of Anna von Waldow. But whereas Von Waldow's propensity for staging exchanges of information between Africans and Germans diminished towards the end of her career, Dörfer's persistent style, of intimately reporting her discerning observations for the eyes of a strategically selected recipient, won her African and European confidantes willing to return the conversation. On rare occasions, Dörfer deemed it necessary to include in her reports to the Berlin Mission translations of personal letters from members of her African congregations. The appearance of some of these letters amongst Dörfer's official correspondence with the BMS suggests that more might have been received. One example is a letter she received from Caroline Makwela in 1967, when in retirement at her Mother House (in Bad Gandersheim in West Germany). Makwela was one of the members of the Lutheran community near the Kreuzburg mission station in the Transvaal. She wrote shortly after the community, having been identified as a 'black spot' within 'white territory', had been forcibly relocated by the South African government. The inhabitants were moved into tents on two farms some eighty kilometres east of their former home. ${ }^{54}$

Hearty greetings to you, our sister. We are alive with the help of the Lord. When I came home, to Kreuzburg, I found that you, our sister, have already left us. It killed my heart that I couldn't find you any more. My other grief was that my house had already been demolished. Truly, Sister, this was a great grief for me. I am a widow, I had hoped that the house of my husband could become my home. Now everything is over, only sorrow has remained. On 23 June during my school holiday I came home, but it was a holiday of suffering. We were moved with lorries and we are now living in tents, until September, then the government will remove the tents again. When they told us we would go to a good place, they did not speak the truth. 'No, no, no.' There are no trees, just thorn bushes and sand. It is a wilderness. What can we do? We weep like the people of Israel, when they sat by the rivers of Babilon and thought of Zion. We too hung our harps on the thorn trees and cried. Psalm 137. Before us lies a land with no consolation. Oh our God! How hard this is! Here on earth there is nobody but you, King Jehovah, who relieves us of our burdens which are pressing us down. The God of all times had given us a time of bitter suffering and ... It is cold and it has rained and hailed. Many of us are ill. There are no shops where we can buy food. We hope that our heavenly father could give you another possibility to work in Africa. Please, please, pray for us. I wish I had wings like a dove. I would have flown, without rest, until I could see you again, Sister.

Pray for us who live in the land of darkness and who do not have a home. It is true, what the song says: My home is not on this earth.

We give thanks for those who have already died and may stand in front of the throne of the Lamb in joy.

Live well, live well in the Lord! The Saviour protect you, and may you have a lot of joy.

I am eternally yours in the Lord,

${ }^{54}$ A. Schultze, In Gottes Namen Hütten bauen (Stuttgart, Franz Steiner, 2005) p 487. 


\section{Catharina Makwela}

\subsubsection{7}

In a sense, Makwela's evidence inverts the intention of the life story formula which had been so popular in missionary publications at the beginning of the twentieth century. This proselyte of the mission church does not tell the story of how she was lost and how the mission came to her rescue. Rather, her story, while couched in the biblical language of exile and lament, bears testimony to the mission society's inability to help her in the face of colonialism and, specifically, apartheid. ${ }^{56}$ All that remained was the personal relationship between two women who, to a certain extent, shared a common view of the world, such that the devastated Makwela could attempt to derive some shared spiritual consolation in her 'land of darkness'.

\section{Conclusion}

What can be read in the German deaconesses' correspondence about African women's daily lives is a recording not simply of the growth of their faith but also of their claims to respectability and security in a colonial world. These tactics are far more apparent in prolonged correspondence through letters than in the more conventional and formulaic 'conversion biographies' found in missionary publications . As historians we should continually check our attempts to extract from correspondence, and thus to decontextualise, scattered morsels of information with a view to collating them into something resembling the life histories which missionary societies used to compose for home consumption. The biographical fragments embedded in the deaconesses' network of correspondence between Germany and Africa are remarkable for the very reason that they can be studied as they appear: in the discursive dynamic of the epistolary form. Any attempt to present the biographical information about these female African Christians separately from the wider reportage of their interaction with the deaconesses who were responsible for constructing and disseminating the knowledge, would close off possibilities of imagining alternative interpretations of the local women's self-presentation.

Von Waldow and Dörfer's letters can thus be approached not only as a vehicle towards biographies of these German sisters, but as a way of accessing the profiles of their African friends and fellow-believers. These profiles comprise numerous small vignettes of African women who led fairly ordinary lives, but were Lutheran Christians, and thereby claimed a presence beyond the immediate and the local. Through the act of writing and collective reading, African women, whose individual identities often disappear in blanket categorisations such as 'ethnic', 'tribal',

\footnotetext{
55 BMW 3030: C. Makwela to A. Dörfer, Bad Gandersheim, 14 August 1967. Andrea Schultze, In Gottes Namen, p. 475, quoted extracts from this letter as she found it translated in the station file for the Kreuzburg Mission Station (1939-1967) in the Berlin Mission archives. To her the document was of exceptional value as the only piece of contemporary evidence she was able to find which showed how this congregation experienced their forced removal. Regrettably, the original letter in Northern Sotho seems to have been lost.

${ }^{56}$ In her study of the BMS and land ownership in South Africa, Schultze criticised the way in which the Superintendent of the Society, in his official report, expressed his admiration for the precision and orderliness with which the apartheid government managed the process, and the disciplined cooperation of the congregation. In an interview with Schultze in the late 1990s, one of the members of the congregation said of the missionaries: 'They did try to speak for us, but couldn't do much ...' and 'People were against the removal, but we didn't resist - it's the government'. See Schultze, In Gottes Namen, pp. 490-492.
} 
'colonised', 'conservative' or 'Westernised', ensured the recording, in writing, of not only the complexity of their identities and the dignity of their survival strategies, but also the grandeur of their aspirations and their adaptability in the face of unfulfilled dreams. 